\title{
Study of the Electrical Conductivity of Al(III) Doped $\mathrm{Sr}_{0.6} \mathrm{Na}_{0.4} \mathrm{SiO}_{3-\alpha}$
}

\author{
Ruijuan Shi, Ruifeng Du, Junlong Liu*, Hongtao Wang* \\ School of Chemical and Material Engineering, Fuyang Normal University; Anhui Provincial Key \\ Laboratory for Degradation and Monitoring of Pollution of the Environment, Fuyang 236037, China \\ *E-mail: hwang@fync.edu.cn; jlliu@fync.edu.cn
}

doi: $10.20964 / 2019.06 .33$

Received: 1 March 2019 / Accepted: 2 April 2019 / Published: 10 May 2019

$\mathrm{Sr}_{1-x} \mathrm{Na}_{x} \mathrm{SiO}_{3-0.5 x}$ is receiving worldwide attention as the fast oxide ion conductor. $\mathrm{Sr}_{0.6} \mathrm{Na}_{0.4} \mathrm{Si}_{0.9} \mathrm{Al}_{0.1} \mathrm{O}_{3-}$ $\alpha$ and $\mathrm{Sr}_{0.6} \mathrm{Na}_{0.4} \mathrm{SiO}_{3-\alpha}$ were successfully fabricated using a solid state synthesis method and characterized with X-ray diffractometer (XRD) and scanning electron microscopy (SEM). From the results of XRD and SEM, it was demonstrated that both samples consist of crystalline $\mathrm{SrSiO}_{3}$ and amorphous $\mathrm{Na}_{2} \mathrm{Si}_{2} \mathrm{O}_{5}$. The $\mathrm{Al}^{3+}$ ion doping in the $\mathrm{Sr}_{1-x} \mathrm{Na}_{x} \mathrm{SiO}_{3-\alpha}$ system led to the decrement of the amorphous Na-rich phase, and extended the scope of the oxide ionic conduction, though it resulted in a negative effect on the conductivity.

Keywords: Strontium silicate; Electrolyte; Fuel cell; Conductivity

\section{$\underline{\text { FULL TEXT }}$}

(C) 2019 The Authors. Published by ESG (www.electrochemsci.org). This article is an open access article distributed under the terms and conditions of the Creative Commons Attribution license (http://creativecommons.org/licenses/by/4.0/). 